\title{
Botulinum toxin therapy: functional silencing of salivary disorders
}

\author{
Terapia con tossina botulinica: silenziamento funzionale dei disordini salivari \\ A. LOVATO ${ }^{1}$, D.A. RESTIVO², G. OTTAVIANO ${ }^{3}$, G. MARIONI ${ }^{3}$, R. MARCHESE-RAGONA ${ }^{3}$ \\ ${ }^{1}$ Department of Neuroscience DNS, University of Padova, Audiology Unit at Treviso Hospital, Treviso, Italy; \\ ${ }^{2}$ Department of Internal Medicine, Neurologic Unit, Nuovo "Garibaldi" Hospital, Catania, Italy; ${ }^{3}$ Otolaryngology \\ Section, Department of Neuroscience DNS, University of Padova, Italy
}

\begin{abstract}
SUMMARY
Botulinum toxin (BTX) is a neurotoxic protein produced by Clostridium botulinum, an anaerobic bacterium. BTX therapy is a safe and effective treatment when used for functional silencing of the salivary glands in disorders such as sialoceles and salivary fistulae that may have a post-traumatic or post-operative origin. BTX injections can be considered in sialoceles and salivary fistulae after the failure of or together with conservative treatments (e.g. antibiotics, pressure dressings, or serial aspirations). BTX treatment has a promising role in chronic sialadenitis. BTX therapy is highly successful in the treatment of gustatory sweating (Frey's syndrome), and could be considered the gold standard treatment for this neurological disorder.
\end{abstract}

KEY WORDS: Botulinum toxin • Sialocele $\bullet$ Salivary fistula $\bullet$ Chronic sialadenitis $\bullet$ Frey’s syndrome

\section{RIASSUNTO}

La tossina botulinica è una neurotossina prodotta dal batterio anaerobio Clostridium botulinum. L'iniezione di tossina botulinica è un trattamento sicuro ed efficace quando viene usata per inibire la funzione delle ghiandole salivari in patologie come gli sialoceli o le fistole salivari di origine post-traumatica o iatrogena. Negli scialoceli e fistole salivari, il trattamento con tossina botulinica può essere preso in considerazione anche dopo il fallimento o in aggiunta ai trattamenti conservativi non chirurgici. La terapia con tossina botulinica si sta dimostrando promettente anche nel trattamento della scialoadenite cronica. La tossina botulinica ha un elevato tasso di risoluzione nella Sindrome di Frey ed è considerata il gold standard nel trattamento di questo disturbo neurologico.

PAROLE CHIAVE: Tossina botulinica $\bullet$ Sialocele $\bullet$ Fistola salivare $\bullet$ Scialoadenite cronica $\bullet$ Sindrome di Frey

Acta Otorhinolaryngol Ital 2017;37:168-171

\section{Introduction}

Botulinum toxin (BTX) is produced by Clostridium botulinum, an anaerobic bacterium. The bacterium produces seven serological types of toxins (A, B, C1, D, E, F and G) as a complex mixture of neurotoxic polypeptides and nontoxic protein components ${ }^{1}$. BTX type A (BTX-A) and B (BTXB) are commercialised and available for medical use ${ }^{2}$.

The application by injection of BTX on salivary glands was first proposed in 1997 as treatment for sialorrhoea ${ }^{3}$, and in 1999 we proposed BTX injection in parotid sialocele ${ }^{4}$. The toxin is able to depress secretory activity of the salivary glands reducing saliva production. At neuromuscular junctions, BTX inhibits presynaptic acetylcholine release by interfering with the neuroexocytosis process, and causes flaccid muscle paralysis ${ }^{5}$. With the same mechanism, BTX on salivary glands acts on the cholinergic nerve terminals (parasympathetic nerve terminals), and produces a local chemical blocking and loss of neuronal activity ${ }^{3}$.
The localised cholinergic block achieved by BTX injection inhibits salivary flow and allows healing of salivary disorders. BTX therapy has been effectively used in various salivary disorders, such as salivary fistulae after sialadenectomy ${ }^{67}$, post-traumatic and iatrogenic salivary sialoceles ${ }^{8-10}$ and chronic sialadenitis ${ }^{11}$. BTX has also been successfully used to treat auriculo-temporal (or Frey's) syndrome ${ }^{12}{ }^{13}$, as it reduced the skin area affected by gustatory sweating by inhibiting the sweat glands abnormally re-innervated after parotidectomy by the cholinergic pathway ${ }^{14}$.

In the present paper, we critically review the current indications and treatment modalities for BTX therapy in salivary gland disorders (and in Frey's syndrome).

\section{Salivary fistula and sialoceles}

Parotid fistula is a chronic wound of the gland or its duct through which saliva is discharged ${ }^{15}$. Sialocele is a collection or retention of saliva in the gland soft tissue. 
Salivary fistulae and sialoceles may occur after penetrating injuries of the salivary glands (in peacetime practice mainly due to shattered glass in road accidents), or as a complication of partial parotidectomy ${ }^{16}$. Parotid fistula has also been reported after rhytidectomy, mastoidectomy, dental extraction, temporomandibular joint surgery and mandibular osteotomy ${ }^{7}$; submandibular sialocele can be due to sialoadenectomy ${ }^{9}$. According to our experience with post-operative parotid fistula ${ }^{7}$, after an initial (4 to 8 postoperative days) swelling beneath the wound in the area overlying the parotid, an efflux of clear fluid from the wound occurs. The flow through the fistula increases during meals, particularly during mastication. In dubious cases, analysis of the fluid can confirm parotid secretion because of to its high amylase content ${ }^{7}$.

Sialocele and salivary fistula, especially when post-traumatic, can be managed by conservative non-operative treatment that includes antibiotics, pressure dressings and serial aspirations ${ }^{17}$. With conventional management techniques, it is very difficult to abolish salivary flow and resolving these salivary disorders may take time, involving a lengthy hospital stay and considerable discomfort. Wax and Tarshis ${ }^{15}$ successfully treated 14 cases of post-parotidectomy fistula with pressure dressing; 9 cases healed after 2 to 9 days, whereas the others needed 10 to 36 days of treatment (average period 21 days). Systemic anticholinergic drugs (which may temporarily lead to a reduction in salivary secretion) may be associated, but they often cause distressing side effects ${ }^{18}$, including dryness of the mouth, blurred vision, urine retention, photophobia, tachycardia, palpitation and anhydrosis with heat intolerance ${ }^{19}$. In the treatment of parotid fistulae, the several therapies that have been described (i.e. pressure dressing, systemic anticholinergic drugs, suction drain insertion, tympanic neurectomy with or without chorda tympani section, surgery and use of 2-octyl cyanoacrylate in persistent cases) frequently show disappointing outcomes ${ }^{2021}$. Considering parotidectomy completion, post-operative fibrosis makes it difficult to dissect the tissue plane with frequent permanent facial paralysis ${ }^{22}$.

In order to avoid surgical management, BTX therapy could be used to obtain a temporary functional silencing of the salivary glands and to allow sialocele and fistula healing ${ }^{11}$. Lim and Choi ${ }^{23}$ successfully treated a parotid salivary fistula with one BTX injection as the only primary therapy without pressure dressing. BTX treatment has proven successful for the treatment of salivary fistula and sialocele, either post-traumatic or post-operative ${ }^{6-11} 16171923-25$. Capaccio et al. ${ }^{24}$ reported the treatment by BTX of 3 patients with salivary fistula and 5 with sialocele: complete clinical recovery was observed in all but one patients. Furthermore, the authors focused on the need for a combination of traditional percutaneous aspiration of extravasated fluid and BTX injection to avoid invasive sialadenectomy ${ }^{24}$, as also proposed by other authors ${ }^{16}$. Laskawi and colleagues ${ }^{25}$ reviewed their experience with BTX treatment in 12 post-parotidectomy salivary fistulae; they reported $90 \%$ of successful fistula closures if early treatment (within 6 weeks after development of the fistula) was performed. Considering the results of our clinical experience with post-operative fistula (16 cases to date), we suggested early BTX treatment to avoid the epithelial coating of the fistulous tract ${ }^{7}$.

\section{Chronic sialadenitis}

BTX was used for the first time for the treatment of 2 cases of chronic sialadenitis by Ellies et al. ${ }^{11}$. They suggested that a temporary silencing of the gland might promote the regeneration of the gland tissue, avoiding gland excision, which is often necessary in recurrent chronic sialadenitis ${ }^{11}$. Treatment with BTX in chronic sialadenitis due to Stensen's duct strictures was effective in reduction of recurrent parotitis ${ }^{24}$ and gland swelling ${ }^{26}$. Traditional treatment options for parotid duct strictures included conservative methods, such as antibiotics, analgesics, or selfmassage of the gland ${ }^{27}$. As second-line therapy, minimally invasive sialendoscopic dilation of the duct has to be considered ${ }^{26}$, using BTX therapy only in persistent cases after sialendoscopy. Recently, BTX was also used in two cases of Sjögren's syndrome-associated recurrent parotitis with good outcomes ${ }^{28}{ }^{29}$. For these salivary gland disorders, it appears that BTX injections at regular intervals are needed (every 3-4 months), as temporary silencing of the glands would not be sufficient ${ }^{29}$.

\section{Frey's syndrome}

A quite frequent and well-described complication of parotidectomy is gustatory sweating or Frey's syndrome. The pathogenesis is based on the aberrant regeneration of sectioned parasympathetic secretomotor fibres of the auriculo-temporal nerve with inappropriate innervation of the cutaneous facial sweat glands that are normally innervated by sympathetic cholinergic fibres ${ }^{30}$. As a consequence, Frey's syndrome is a disorder characterised by unilateral sweating and flushing of the facial skin in the area of the parotid gland occurring during meals that usually becomes evident $1-12$ months after surgery ${ }^{30}$. According to a survey of post-parotidectomy patients, the incidence of Frey's syndrome was $23 \%$, while it was observed in $62 \%$ of cases using Minor's starch-iodine test ${ }^{31}$. The Minor test is usually used to identify and mark the margins of the area involved by gustatory sweating.

Systemic or topical application of various anticholinergic agents (scopolamine, glycopyrrolate, diphemnanilmethylsulfate) and surgical treatment (including cervical sympathectomy, tympanic neurectomy, sternocleidomastoid transfer and dermis-fat grafts and the use of various materials, as interpositional barriers) have been proven 
unsuccessful for Frey's syndrome ${ }^{32}$. On the contrary, good results have been obtained by local injection of BTX, as the neurotoxin inhibits pre-synaptic acetylcholine release, reducing eccrine glands secretions and sweating ${ }^{32}$. The gustatory sweating usually ceased in the treated area within 48-72 hours after the first BTX injection.

Treatment with BTX in Frey's syndrome reduces hyperhidrosis and facial gustatory flushing, as described by Tugnoli et colleagues ${ }^{33}$. A recent systematic metaanalysis by Xie et al. ${ }^{34}$ on the effectiveness of BTX-A therapy for Frey's syndrome reported an effective rate of more than $98 \%{ }^{34}$. In 2001, Tugnoli et al. described the treatment of Frey's syndrome with BTX type F (BTX-F) in a patient with immuno-resistance to BTX-A ${ }^{35}$. BTX was also effective in diabetic autonomic gustatory sweating; in 2002 Restivo et al. treated with success 14 diabetic subjects with gustatory sweating ${ }^{36}$. We can currently state that BTX injections is the gold standard treatment for Frey's syndrome.

\section{Discussion}

BTX has proven to be efficient in the treatment of salivary disorders such as sialocele ${ }^{24}$ and salivary fistula ${ }^{25}$. Furthermore, BTX may have an emergent role in the treatment of chronic sialadenitis ${ }^{29}$. BTX injections are effective in most of the patients with Frey's syndrome ${ }^{34}$. The majority of authors used BTX-A for salivary gland disorders ${ }^{24} 2537$ and gustatory sweating ${ }^{31}$, even if the use of BTX-B ${ }^{16}$ and BTX-F ${ }^{35}$ has been described in salivary gland disease.

The dose of BTX-A injected in the parotid gland, to treat sialoceles and salivary fistulae, varied in different studies from 10 to 60 mouse units (MU) ${ }^{71124}$. Capaccio et al. ${ }^{24}$ used 25 to $60 \mathrm{MU}$ per treatment fractionated into 4 doses as the parotid was divided into anterior, posterior, upper, and lower quadrants. In their case series, the authors treated drooling, salivary fistulae, sialoceles and recurrent parotitis, without giving precise indications regarding the doses used in the different entities ${ }^{24}$. Treating post-parotidectomy salivary fistulae, we had complete healing of all the fistulae using a single lower dose (10 to $20 \mathrm{MU}$ ) fractionated in 3 doses (two for the superior and one for the inferior lobe) ${ }^{7}$. For post-parotidectomy fistulae, Laskawi et al. ${ }^{25}$ reported a total dose of BTX-A between 10 and $40 \mathrm{U}$, depending on the size of the remaining glandular compartment. The injections were performed into the gland at two to three sites; three patients got two injections because of persistent leakage of saliva after the first injection ${ }^{25}$. In Frey's syndrome, the area identified by the Minor test is divided into 1 or $1.5 \mathrm{~cm}$ squares, and $2 \mathrm{MU}$ of BTX-A are injected, subcutaneously, into each square to achieve a diffuse, homogeneous effect ${ }^{2432}$.

In cases of parotid salivary fistulae, we injected BTX under electromyographic (EMG) control on an ambulatory basis with little discomfort. We used a tuberculin syringe with a 27-gauge monopolar Teflon-coated hollow EMG recording needle connected to an EMG recorder for the injection. To prevent the masseter and pterygoideus muscles from improperly weakening with the needle in place, patients were instructed to open and close their mouths, and the EMG signals were observed ${ }^{738}$. Other authors used ultrasonographic-assisted intraparenchymal infiltration ${ }^{112425}$. Both techniques were effective and with few reported mild complications, such as transitory paresis of the lower branch of the facial nerve ${ }^{11}$ and change of saliva thickness ${ }^{38}$. Injections for Frey's syndrome should also be considered safe as only transient paresis of the orbicularis oris, in very few cases, has been reported ${ }^{32}$.

In view of the effectiveness and the absence of significant side effects in treatment of parotid fistula and sialocele, BTX therapy may be indicated as a precautionary treatment both in partial parotidectomies and in the management of deep facial wounds that affect the parotid gland ${ }^{7}$. Recently, to avoid the onset of salivary complications, the use of BTX has been proposed after facial transplantation ${ }^{39}$.

\section{Conclusions}

BTX injection is a safe and effective treatment when used for functional silencing of the salivary glands in disorders such as sialoceles and salivary fistulae, and also shows a promising role in chronic sialadenitis therapy. BTX therapy is highly successful in the treatment of gustatory sweating (Frey's syndrome), and could be considered the gold standard treatment for this post-parotidectomy complication.

\section{References}

1 Tsui JK. Botulinum toxin as a therapeutic agent. Pharmacol Ther 1996;72:13-24.

2 Oliveira JB, Evêncio-Neto J, Baratella-Evêncio L. Histological and immunohistochemical findings of the action of botulinum toxin in salivary gland: systematic review. Braz J Biol 2016. [Epub ahead of print]

3 Bushara KO. Sialorrhea in amyotrophic lateral sclerosis: a hypothesis of a new treatment - botulinum toxin A injections of the parotid glands. Med Hypotheses 1997;48:337-9.

4 Marchese-Ragona R, Blotta P, Pastore A, et al. Management of parotid sialocele with botulinum toxin. Laryngoscope 1999;109:1344-6.

5 Sollner T, Bennett MK, Whiteheart S, et al. A protein assembly-disassembly pathway in vitro that may correspond to sequential steps of synaptic vesicle docking, activation, and fusion. Cell 1993;75:409-18.

6 Marchese-Ragona R, Galzignato PF, Marioni G, et al. Endoscopic diagnosis of rhino-parotid fistula and successful treatment with botulinum toxin. Laryngoscope 2005;115:2062-4.

7 Marchese-Ragona R, Marioni G, Restivo AD, et al. The role of botulinum toxin in postparotidectomy fistula treatment. A technical note. Am J Otolaryngol 2006;27:221-4. 
8 Capaccio P, Paglia M, Minorati D, et al. Diagnosis and therapeutic management of iatrogenic parotid sialocele. Ann Otol Rhinol Laryngol 2004;113:562-4.

9 Capaccio P, Cuccarini V, Benicchio V, et al. Treatment of iatrogenic submandibular sialocele with botulinum toxin. Case report. Br J Oral Maxillofac Surg 2007;45:415-7.

10 Arnaud S, Batifor D, Goudot P, et al. Nonsurgical management of traumatic injuries of the parotid gland and duct using type A botulinum toxin. Plast Reconstr Surg 2006;117:2426-30.

11 Ellies M, Gottstein U, Rohrbach-Volland S, et al. Reduction of salivary flow with botulinum toxin: extended report on 33 patients with drooling, salivary fistulas, and sialadenitis. Laryngoscope 2004;114:1856-60.

12 Laskawi R, Drobik C, Schonebeck C. Up-to-date report of botulinum toxin type A treatment in patients with gustatory sweating (Frey's syndrome). Laryngoscope 1998;108:381-4.

13 Restivo DA, Lanza S, Patti F, et al. Improvement of diabetic autonomic gustatory sweating by botulinum toxin type A. Neurology 2002;59:1971-3.

14 Drummond P. Mechanism of gustatory flushing in Frey's syndrome. Clin Auton Res 2002;12:144-6.

15 Wax M, Tarshis L. Post-parotidectomy fistula. J Otolaryngol 1991;20:10-3.

16 Pantel M, Volk GF, Guntinas-Lichius O, Wittekindt C. Botulinum toxin type $b$ for the treatment of a sialocele after parotidectomy. Head Neck 2013;35:E11-2.

17 Gordin EA, Daniero JJ, Krein H, et al. Parotid gland trauma. Facial Plast Surg 2010;26:504-10.

18 Spinell C, Ricci E, Berti P, et al. Postoperative salivary fistula: therapeutic action of octreotide. Surgery 1995;117:117- 8.

19 Landau R, Stewart M. Conservative management of posttraumatic parotid fistulae and sialoceles: a prospective study. Br J Surg 1985;72:42-4.

20 Mandour MA, El-Sheikh MM, El-Garem F. Tympanic neurectomy for parotid fistula. Arch Otolaryngol 1976;102:327-9.

21 Schindel J, Markowicz H, Levie B. Combined surgical-radiological treatment of parotid gland fistulae. J Laryngol Otol 1968;82:867-70.

22 Ananthakrishnan N, Parkash S. Parotid fistulas: a review. $\mathrm{Br}$ J Surg 1982;69:641-3.

23 Lim YC, Choi EC. Treatment of an acute salivary fistula after parotid surgery: botulinum toxin type A injection as primary treatment. Eur Arch Otorhinolaryngol 2008;265:243-5.

24 Capaccio P, Torretta S, Osio M, et al. Botulinum toxin therapy: a tempting tool in the management of salivary secretory disorders. Am J Otolaryngol 2008;29:333-8.
25 Laskawi R, Winterhoff J, Köhler S, et al. Botulinum toxin treatment of salivary fistulas following parotidectomy: follow-up results. Oral Maxillofac Surg 2013;17:281-5.

26 Kruegel J, Winterhoff J, Koehler S, et al. Botulinum toxin: A noninvasive option for the symptomatic treatment of salivary gland stenosis - a case report. Head Neck 2010;32:959-63.

27 Nahlieli O, Bar T, Shacham R, et al. Management of chronic recurrent parotitis: current therapy. J Oral Maxillofac Surg 2004;62:1150-5.

28 Daniel SJ, Diamond M. Botulinum toxin injection: a novel treatment for recurrent cystic parotitis Sjögren syndrome. Otolaryngol Head Neck Surg 2011;145:180-1.

29 O'Neil LM, Palme CE, Riffat F, et al. Botulinum toxin for the management of Sjögren syndrome-associated recurrent parotitis. J Oral Maxillofac Surg 2016; 74:2428-2430.

30 Singh N, Kohli M, Kohli H. Innovative technique to reduce incidence of Frey's syndrome after parotid surgery. Am Surg 2011;77:351-4.

31 Neumann A, Rosenberger D, Vorsprach O, et al. The incidence of Frey syndrome following parotidectomy: results of a survey and follow-up. HNO 2011;59:173-8.

32 Marchese-Ragona R, De Filippis C, Marioni G, et al. Treatment of complications of parotid gland surgery. Acta Otorhinolaryngol Ital 2005;25:174-8.

33 Tugnoli V, Marchese Ragona R, Eleopra R, et al. The role of gustatory flushing in Frey's syndrome and its treatment with botulinum toxin type A. Clin Auton Res 2002;12:174-8.

${ }^{34}$ Xie S, Wang K, Xu T, et al. Efficacy and safety of botulinum toxin type A for treatment of Frey's syndrome: evidence from 22 published articles. Cancer Med 2015;4:1639-50.

35 Tugnoli V, Marchese Ragona R, Eleopra R, et al. Treatment of Frey syndrome with botulinum toxin type $F$. Arch Otolaryngol Head Neck Surg 2001;127:339-40.

36 Restivo DA, Lanza S, Patti F, et al. Improvement of diabetic autonomic gustatory sweating by botulinum toxin type A. Neurology 2002;59:1971-3.

37 Staffieri A, Marchese Ragona R, de Filippis C, et al. Management of parotid fistulae and sialoceles with botulinum toxin. Otolaryngol Head Neck Surg 1999;121:P240-1.

38 Marchese Ragona R, de Filippis C, Staffieri A, et al. Parotid fistula: treatment with botulinum toxin. Plastic Reconst Surg 2001;107:886-7.

39 Frautschi R, Rampazzo A, Bernard S, et al. Management of the salivary glands and facial nerve in face transplantation. Plast Reconstr Surg 2016;137:1887-97. 